NASA

Technical Memorandum 105668
AVSCOM

Technical Report 91-C-035

\title{
Full-Scale Transmission Testing to Evaluate Advanced Lubricants
}

David G. Lewicki and Harry J. Decker

Propulsion Directorate

U.S. Army Aviation Systems Command

Lewis Research Center

Cleveland, Ohio

and

John T. Shimski

Naval Air Propulsion Center

Trenton, New Jersey

Prepared for the

Sixth International Power Transmission and Gearing Conference sponsored by the American Society of Mechanical Engineers Phoenix, Arizona, September 13-16, 1992 


\title{
FULL-SCALE TRANSMISSION TESTING TO EVALUATE ADVANCED LUBRICANTS
}

\author{
David G. Lewicki and Harry J. Decker \\ Propulsion Directorate \\ U.S. Army Aviation Systems Command \\ NASA Lewis Research Center \\ Cleveland, Ohio
}

and

John T. Shimski

Naval Air Propulsion Center

Trenton, New Jersey

\section{ABSTRACT}

Experimental tests were performed on the $\mathrm{OH}-58 \mathrm{~A}$ helicopter main-rotor transmission in the NASA Lewis 500-hp helicopter transmission test stand. The testing was part of a joint Navy/ NASA/Army lubrication program. The objectives of the joint program are to develop and demonstrate a separate lubricant for gearboxes with improved performance in life and load-carrying capacity. The goal of these experiments was to develop a testing procedure to fail certain transmission components using a

MIL-L-23699 based reference oil and then to run identical tests with improved lubricants and demonstrate improved performance. The tests were directed at components that failed due to marginal lubrication from Navy field experience. These failures included mast shaft bearing micropitting, sun gear and planet bearing fatigue, and spiral bevel gear scoring. A variety of tests were performed and over $900 \mathrm{hr}$ of total run time accumulated for these tests. Some success was achieved in developing a testing procedure to produce sun gear and planet bearing fatigue failures. Only marginal success was achieved in producing mast shaft bearing micropitting and spiral bevel gear scoring.

\section{INTRODUCTION}

The U.S. Army helicopters currently use the same lubricant for engines and transmissions. The U.S. Navy employed the same practice until 1987. The lubricant used conforms to either a MIL-L-23699 or a MIL-L-7808 specification. These oils provide satisfactory lubrication for current gas turbine engines but only marginal performance for transmissions. Navy overhaul depots reported increasing rates of rejection of helicopter bearings and gears due to surface distress, corrosion, and wear (Shimski and Paskow, 1985, Brahney, 1986). Navy AH-1T, UH-1N, and UH-1J fleets encountered upper mast shaft bearing distress due to the marginal protection capabilities of the MIL-L-23699 fluids. Navy early production SH-60B helicopters experienced spiral bevel gear surface distress when using these oils. Also, corrosion was a leading cause for rejection of transmission parts at overhaul for Navy CH-46 helicopters, with bearings accounting for most of the rejections. In addition to the marginal performance of the past, the continued use of a common engine and transmission oil will handicap next-generation gearboxes. Potential benefits associated with a dedicated helicopter transmission lubricant have been identified (Drago, 1982, Keller, 1982, Drago et al., 1985). In certain helicopter transmission components, the relatively low speed and high load results in extremely thin elastohydrodynamic film thicknesses between meshing gear teeth and bearing-raceway/rolling-element contacts. This increases the likelihood of metal-to-metal contact and therefore the chance of surface distress in components. The use of a more viscous oil has the potential to improve bearing and gear lives significantly. For gears, tooth bending fatigue is essentially unaffected by the lubricant used. Both durability and scoring resistance, however, are very much a function of the lubricant. A major effect of using an oil with improved load-carrying capacity is to increase the scoring and durability ratings of the gears.

The desired lubricant properties for engines and gearboxes are not the same. The Navy discovered that load-carrying agents added to improve gearbox durability reduced the thermal stability of the lubricant. This, in turn, decreased the fluid's performance when used in an engine. The trends of next-generation engines are for higher operating temperatures for maximizing fuel efficiency. The trends for gearboxes, however, are for reduced weight, improved durability, increased power and load-carrying capacities, and higher temperatures. To meet the needs of future gearboxes and address the above-mentioned field problems, the Navy initiated the Advanced Lubricants Program for helicopter transmissions.

The Naval Air Propulsion Center (NAPC) instituted a threephase program to increase helicopter transmission life and durability through the use of advanced lubricants. The three phases are (1) interim oil phase, (2) optimum oil phase, and (3) advanced oil phase. The intent of the interim oil phase was to provide a transmission lubricant with improved load-carrying capacities to aid those gearboxes currently experiencing problems due to marginal lubrication. The interim oil was a transitional fluid between MIL-L-23699 and the optimum oil. It was compatible with MIL-L-23699 such that accidental mixing would not harm turbine engines. It allowed servicing personnel an interim period for training and adjustment of using a separate oil in the gearbox. To date, specification requirements for the interim oil have been developed. This resulted in the publication of a new specification for a transmission oil, DOD-L-85734 (AS), in 1986. The Navy implemented use of this oil in 1987. 
The goal of the optimum oil phase is to develop a lubricant specially formulated for gearboxes. The lubricant is to have greater load-carrying capacity (about twice that of MIL-L-23699) and improved corrosion inhibiting properties. Candidates for the optimum oil are being developed and evaluated in laboratory and bench testing by oil companies and NAPC. The advanced oil phase (at least a decade or two away) is intended for future aircraft in which the transmissions would operate at high temperature and high loading.

NASA Lewis Research Center and the U.S. Army Propulsion Directorate, with their unique gear and transmission facilities, are supporting the Advanced Lubricants Program. The effect of the lubricant on the gear pitting fatigue life is being studied using the gear fatigue test apparatus at NASA Lewis. It was found that higher viscosity lubricants (compared to MIL-L-23699) with additive packages increased gear life (Townsend and Shimski, 1991).

In addition to the gear tests, full-scale transmission tests were performed in the NASA Lewis 500 -hp helicopter transmission test stand. The Army OH-58A helicopter main-rotor transmission was used for the tests. The objective of the research reported herein was

(1) To develop an experimental testing procedure to simulate transmission failures experienced by the Navy in the field. These failures included planet bearing and sun gear fatigue, mast shaft ball-bearing micropitting, and spiral bevel gear scoring, all of which are related to the lubricant.

(2) To test to failure the above-mentioned components in the OH-58A transmission using a MIL-L-23699 based reference oil and then using the candidate, improved lubricants to demonstrate improved performance.

\section{APPARATUS AND TEST PROCEDURE}

\section{OH-58A Main-Rotor Transmission}

The $\mathrm{OH}-58 \mathrm{~A}$ is a single-engine, land-based, light, observation helicopter. The helicopter serves both military (OH-58 Kiowa) and commercial (Bell Model 206 Jet Ranger) needs. The design maximum torque and speed for the $\mathrm{OH}-58 \mathrm{~A}$ main-rotor transmission (Fig. 1) is $350 \mathrm{~N} \cdot \mathrm{m}$ (3100 in. $\cdot \mathrm{lb}$ ) input torque and $6060 \mathrm{rpm}$ input speed (Warren and Young, 1969). This corresponds to $222 \mathrm{~kW}$ (298 hp). The transmission is a two-stage reduction gearbox with an overall reduction ratio of $17.44: 1$. The first stage is a spiral bevel gear set with a 19-tooth pinion that meshes with a 71-tooth gear. Triplex ball bearings and one roller bearing support the bevel-pinion shaft. Duplex ball bearings and one roller bearing support the bevelgear shaft in an overhung configuration.

A planetary mesh provides the second reduction stage. The bevel-gear shaft is splined to a sun gear shaft. Both a three-planet $(\mathrm{OH}-58 \mathrm{~A})$ and four-planet $(\mathrm{OH}-58 \mathrm{C})$ assembly were used for the tests. For the three-planet assembly, the 27 -tooth sun gear drives three 35 -tooth planet gears. The planet gears mesh with a 99 -tooth fixed ring gear splined to the transmission housing. The planet gears are supported by double-row spherical roller bearings attached to the planet carrier. Power is taken out through the planet carrier splined to the output mast shaft. The output shaft is supported on top by a split-inner-race ball bearing and on bottom by a roller bearing. The four-planet assembly is different from the three-planet in that it has one more planet, the planet bearings are cylindrical rollers rather than spherical, and the planets are straddle mounted by the carrier rather than overhung. The four-planet assembly has significantly higher load-carrying capacity than the three planet.

The 71-tooth bevel gear also drives a 27 -tooth accessory gear. The accessory gear runs an oil pump, which supplies lubrication through jets and passageways located in the transmission housing.

\section{NASA 500-HP Helicopter Transmission Test Stand}

The OH-58A transmission was tested in the NASA Lewis 500-hp helicopter transmission test stand (Fig. 2). The test stand operates on the closed-loop or torque-regenerative principle.

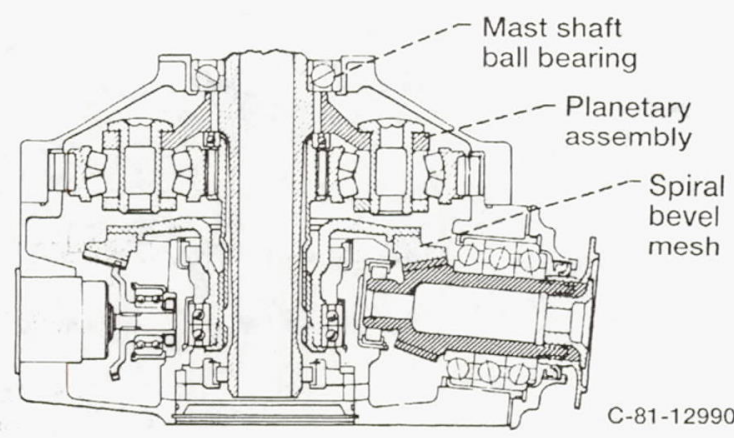

(a) Cross-sectional schematic.

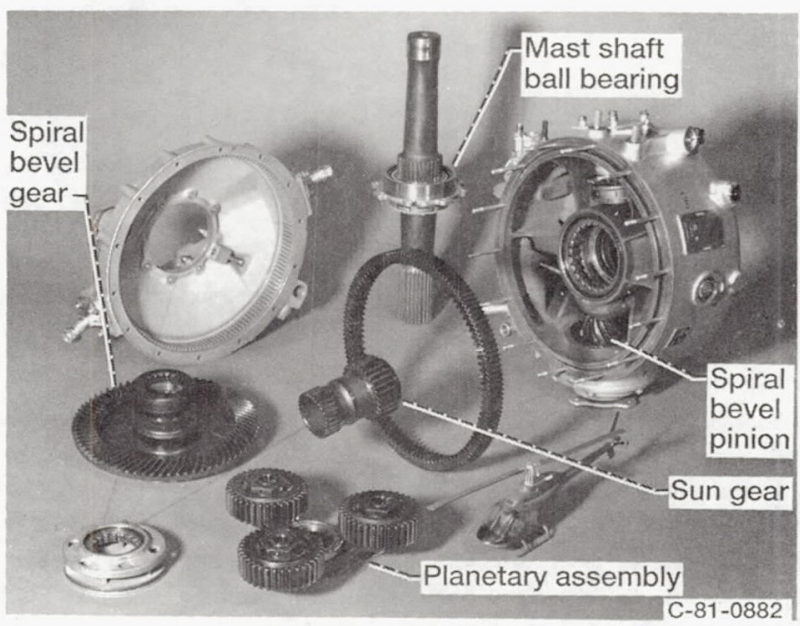

(b) Disassembled view.

FIG. 1.-OH-58A helicopter main rotor transmission.

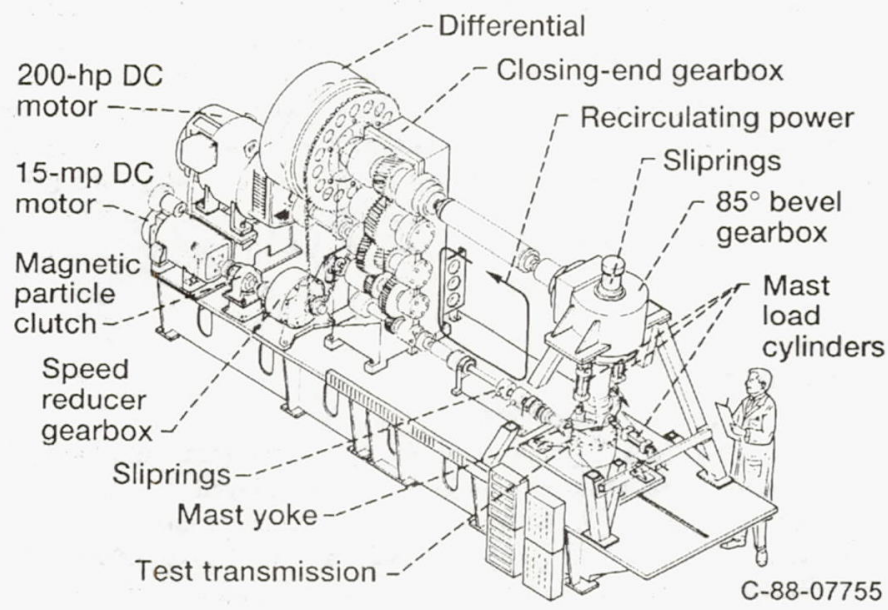

FIG. 2.-NASA Lewis 500-hp helicopter transmission test stanct.

Mechanical power recirculates through a closed loop of gears and shafting, one of which is the test transmission. The output of the test transmission attaches to the bevel gearbox. The output shaft of the bevel gearbox passes through a hollow shaft in the closing-end gearbox and connects to the differential gearbox. The output of the differential attaches to the hollow shaft in the closing-end gearbox. The output of the closing-end gearbox connects to the input of the test transmission, thereby closing the loop.

A $149-\mathrm{kW}$ (200-hp) variable-speed direct-current (d.c.) motor powers the test stand and controls the speed. The motor output attaches to the closing-end gearbox. The motor replenishes only losses due to friction since power recirculates around the loop. 
An 11-kW (15-hp) d.c. motor provides the torque in the closed loop. The motor drives a magnetic particle clutch. For the $\mathrm{OH}-58 \mathrm{~A}$ application, the clutch output does not turn but exerts a torque. This torque transfers through a speed reducer gearbox and a chain drive to a large sprocket on the differential gearbox. The torque on the sprocket puts a torque in the closed loop by displacing the gear attached to the output shaft of the bevel gearbox with the gear connected to the input shaft of the closing-end gearbox. This is done within the differential gearbox through use of a compound planetary system where the planet carrier attaches to the sprocket housing. The magnitude of torque in the loop is adjusted by changing the electric field strength of the magnetic particle clutch.

A mast shaft loading system in the test stand simulates rotor loads imposed on the $\mathrm{OH}-58 \mathrm{~A}$ transmission output mast shaft. The OH-58A transmission output mast shaft connects to a loading yoke. Two vertical load cylinders connected to the yoke produce lift loads. A single, horizontal load cylinder, connected to the yoke, produces shear loads. A $13790-\mathrm{kPa}$ (2000-psig) gas nitrogen system powers the cylinders. Pressure regulators connected to the nitrogen supply of each of the load cylinders adjust the magnitude of lift and shear forces.

The test transmission input and output shafts have speed sensors, torquemeters, and sliprings. All three load cylinders on the mast yoke are mounted to load cells. The test transmission internal oil pump supplies lubrication. An external oil-water heat exchanger cools the test transmission oil. The $149-\mathrm{kW}(200-\mathrm{hp})$ motor has a speed sensor and a torquemeter. The magnetic particle clutch has speed sensors on the input and output shafts and thermocouples. A facility oil-pumping and -cooling system lubricates the differential gearbox, the closing-end gearbox, and the bevel gearbox. The facility gearboxes have accelerometers, thermocouples, and chip detectors for health and condition monitoring.

\section{Testing Procedure}

The component failures of interest for these tests were sun gear and planet bearing fatigue, mast shaft ball-bearing micropitting, and spiral bevel gear scoring. Ten tests were performed (Table I), accumulating over $900 \mathrm{hr}$ of total run time, including test time and warmup time.

The $\mathrm{OH}-58 \mathrm{~A}$ main-rotor transmission used for the testing was from the Corpus Christi Army Depot (CCAD) where it had been overhauled after $1908 \mathrm{hr}$ run time (load history unknown). Only the spiral-bevel-pinion triplex ball bearing and the spiral bevel gear duplex ball bearing were replaced during the overhaul. All other transmission components had $1908 \mathrm{hr}$ on them. Before running at NASA Lewis, the transmission was disassembled, inspected, instrumented, and reassembled. Thermocouples were installed on most bearing races. Slip rings on the transmission input and output shafts extracted the thermocouple signals from the bevel-pinion triplex and roller bearing inner races as well as the planet bearing inner races. Accelerometers were installed at various locations on the transmission housing in a manner similar to that reported by Lewicki and Coy (1987). The intent of the instrumentation was to provide an indication of a component failure during the tests.

Table I. Test operating conditions.

[Tests 2 to 10 at $6080 \mathrm{rpm}$ transmission input speed, $1 \%$ oil flow rate to mast ball bearing.]

\begin{tabular}{|c|c|c|c|c|c|c|c|c|}
\hline Test & $\begin{array}{l}\text { Test } \\
\text { time, } \\
\mathrm{hr}\end{array}$ & $\begin{array}{c}\text { Trans- } \\
\text { mission } \\
\text { input } \\
\text { torque, } \\
\% \text { of } \\
\text { design max } \\
\end{array}$ & $\begin{array}{l}\text { Mast } \\
\text { radial } \\
\text { load, } \\
\% \text { of } \\
\text { design } \\
\text { max } \\
\end{array}$ & $\begin{array}{l}\text { Trans- } \\
\text { mission } \\
\text { inlet } \\
\text { temper- } \\
\text { ature, } \\
{ }^{\circ} \mathrm{C}\left({ }^{\circ} \mathrm{F}\right) \\
\end{array}$ & Oil type & $\begin{array}{c}\text { Mast bearing } \\
\text { ball surface } \\
\text { roughness, } \\
\mu \mathrm{m} \text { AA } \\
(\mu \text { in. AA) }\end{array}$ & Other & $\begin{array}{l}\text { Component } \\
\text { failures }\end{array}$ \\
\hline 1 & 71 & --- & $\cdots$ & $-\cdots$ & $\begin{array}{c}\text { MIL-L-23699 } \\
\text { Brand A }\end{array}$ & 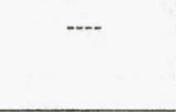 & $\begin{array}{l}\text { Parametric studies of effect } \\
\text { of speed, load, temp, and oil } \\
\text { pressure on performance }\end{array}$ & None \\
\hline 2 & 100 & 100 & 110 & $82(180)$ & $\begin{array}{l}\text { MIL-L-23699 } \\
\text { Brand A }\end{array}$ & $\cdots$ & & $\begin{array}{l}\text { Spiral bevel } \\
\text { pinion spall }\end{array}$ \\
\hline 3 & 50 & 117 & 110 & $121(250)$ & $\begin{array}{l}\text { MIL-L-23699 } \\
\text { Brand A }\end{array}$ & --- & & $\begin{array}{l}\text { Sun gear spall, } \\
\text { spiral bevel } \\
\text { heavy wear/ } \\
\text { scoring }\end{array}$ \\
\hline 4 & 50 & 100 & 110 & $121(250)$ & $\begin{array}{l}\text { MIL-L-23699 } \\
\text { Brand A }\end{array}$ & 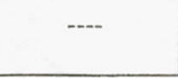 & & None \\
\hline 5 & 75 & 117 & 110 & $121(250)$ & $\begin{array}{c}\text { MIL-L-23699 } \\
\text { Brand A }\end{array}$ & $0.53(21)$ & & $\begin{array}{l}\text { Two planet } \\
\text { bearing spalls }\end{array}$ \\
\hline 6 & 100 & 117 & 110 & $121(250)$ & $\begin{array}{l}\text { MIL-L-23699 } \\
\text { Brand A }\end{array}$ & $0.56(22)$ & $\begin{array}{l}40 \% \text { oil flow rate to spiral } \\
\text { bevel mesh \& 4-planet } \\
\text { system used for last } 25 \mathrm{hrs} \\
\text { of test }\end{array}$ & $\begin{array}{l}\text { Planet bearing } \\
\text { spall, sun gear } \\
\text { spall }\end{array}$ \\
\hline 7 & 100 & 117 & 132 & $121(250)$ & $\begin{array}{l}\text { MIL-L-23699 } \\
\text { Brand A }\end{array}$ & $0.81(32)$ & $\begin{array}{l}21 \% \text { oil flow rate to spiral } \\
\text { bevel mesh; reduced oil } \\
\text { level; 4-planet system used }\end{array}$ & None \\
\hline 8 & 100 & 117 & 110 & $121(250)$ & $\begin{array}{c}\text { MIL-L-23699 } \\
\text { Brand B } \\
\end{array}$ & $0.81(32)$ & $\begin{array}{l}21 \% \text { oil flow rate to spiral } \\
\text { bevel mesh; reduced oil level }\end{array}$ & $\begin{array}{l}\text { Two sun gear } \\
\text { spalls/scoring }\end{array}$ \\
\hline 9 & 91 & 117 & 110 & $121(250)$ & $\begin{array}{l}\text { MIL-L-23699 } \\
\text { Brand B }\end{array}$ & $\cdots$ & $\begin{array}{l}21 \% \text { oil flow rate to spiral } \\
\text { bevel mesh; reduced oil level }\end{array}$ & $\begin{array}{l}\text { Planet bearing } \\
\text { cage failure }\end{array}$ \\
\hline 10 & 100 & 117 & 110 & $121(250)$ & DOD-L-85734 & $0.61(24)$ & $\begin{array}{l}21 \% \text { oil flow rate to spiral } \\
\text { bevel mesh; reduced oil level }\end{array}$ & None \\
\hline
\end{tabular}


Test 1 consisted of parametric studies of the effect of speed, load, temperature, and oil pressure on $\mathrm{OH}-58 \mathrm{~A}$ transmission performance. Information from an analysis performed on the $\mathrm{OH}-58 \mathrm{~A}$ transmission (Lewicki et al., 1991, Appendix A) and the results from the parametric studies (Lewicki et al., 1991, Appendix B) were used to set the parameters expected to produce failure. Tests 2 to 7 concentrated on developing a testing procedure to fail the desired components using the MIL-L-23699 lubricant. (Lubricant properties are given in Table II.) The tests were performed sequentially, with the results of each test used to set the conditions of the next. Tests 8 and 9 concentrated on repeating the results from tests 2 to 7 but with a second commercial brand of MIL-L-23699 lubricant.

Test 10 was a repeat of test 8 but using a DOD-L-85734 lubricant. The physical and chemical properties of the MIL-L-23699 and DOD-L-85734 lubricants (viscosity, flash and pour points, acidity, etc.) are similar. The DOD-L-85734 lubricant has significantly higher load-carrying capacity as indicated by the Ryder Gear ratings (and somewhat by the four ball wear tests).

Table II. Measured properties of MIL-L-23699 and DOD-L-85734

\begin{tabular}{|c|c|c|c|}
\hline Parameter & $\begin{array}{c}\text { MIL-L-23699 } \\
\text { Brand A }\end{array}$ & $\begin{array}{c}\text { MIL-L-23699 } \\
\text { Brand B }\end{array}$ & DOD-L-85734 \\
\hline $\begin{array}{l}\text { Kinematic viscosity, } \\
\mathrm{cS} \text {, at - } \\
\begin{array}{l}38^{\circ} \mathrm{C}\left(100^{\circ} \mathrm{F}\right) \\
99^{\circ} \mathrm{C}\left(210^{\circ} \mathrm{F}\right)\end{array}\end{array}$ & $\begin{array}{c}27.02 \\
5.03 \\
\end{array}$ & $\begin{array}{c}26.47 \\
5.08 \\
\end{array}$ & $\begin{array}{c}28.15 \\
5.35 \\
\end{array}$ \\
\hline Flash point, ${ }^{\circ} \mathrm{C}\left({ }^{\circ} \mathrm{F}\right)$ & $260(500)$ & $280(500)$ & $254(490)$ \\
\hline Pour point, ${ }^{\circ} \mathrm{C}\left({ }^{\circ} \mathrm{F}\right)$ & $-59(-75)$ & $-57(-70)$ & $-62(-80)$ \\
\hline $\begin{array}{l}\text { Total acid number, } \\
\mathrm{mg} \mathrm{KOH} / \mathrm{g}\end{array}$ & 0.00 & 0.37 & 0.40 \\
\hline $\begin{array}{c}\text { Rubber compatibility }{ }^{\mathrm{a}} \text {, } \\
\text { H - type, swell, \% } \\
\text { F - type, swell, \% } \\
\text { Silicon, swell, } \% \\
\text { Silicon, tensile } \\
\text { loss, } \%\end{array}$ & $\begin{array}{r}12 \\
13 \\
15 \\
9\end{array}$ & $\begin{array}{r}16.1 \\
15.3 \\
8.6 \\
16.3\end{array}$ & $\begin{array}{c}10.5 \\
13.1 \\
0 \\
55.3\end{array}$ \\
\hline $\begin{array}{l}\text { Ryder gear load capac- } \\
\text { ity, \% reference oil }\end{array}$ & 122 & 122 & 164 \\
\hline $\begin{array}{l}\text { Four ball wear test, } \\
\text { wear scar diameter, } \\
\text { mm } \\
\begin{array}{l}10 \mathrm{~kg} \\
40 \mathrm{~kg}\end{array}\end{array}$ & $\begin{array}{l}0.569 \\
0.867\end{array}$ & $\begin{array}{l}0.251 \\
0.424\end{array}$ & $\begin{array}{l}0.239 \\
0.394 \\
\end{array}$ \\
\hline
\end{tabular}

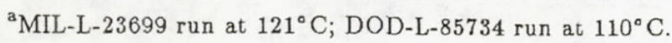

\section{RESULTS AND DISCUSSION}

Analytical and Experimental Parametric Studies

A bending and contact stress analysis using American Gear Manufacturers Association (AGMA) standards was performed on gears in the $\mathrm{OH}-58 \mathrm{~A}$ transmission main power train. Based on the AGMA stress analysis, it was concluded that $262 \mathrm{~kW}$ ( $351 \mathrm{hp}$ ) was the highest load to operate the $\mathrm{OH}-58 \mathrm{~A}$ transmission to promote planetary pitting fatigue failures but not tooth bending fatigue failures. A scoring analysis was performed on the spiral bevel gear mesh using a method by Drago (1988). For conditions up to $275 \mathrm{~kW}(369 \mathrm{hp})$ and $121^{\circ} \mathrm{C}\left(250^{\circ} \mathrm{F}\right)$ oil inlet temperature, a low probability of scoring was predicted. The planet bearing, planet gear, and mast shaft ball bearing were analyzed using methods of Klecker et al. (1982), Wang and Cheng (1981a, 1981b), and Hadden et al. (1981). These components had extremely low predicted film thicknesses, implying a high probability of surface related problems and that the influence of the lubricant could be significant. The results of the experimental parametric studies gave trends of the effect of speed, torque, and oil temperature on transmission performance. A detailed description of these results is given in Appendixes A and B of Lewicki et al. (1991).

\section{Planetary Results}

Some success was achieved in developing a testing procedure to produce sun gear and planet bearing fatigue failures. A total of three planet bearing fatigue failures (along with one planet bearing cage failure) and four sun gear failures were produced using MIL-L-23699 lubricants (Fig. 3).

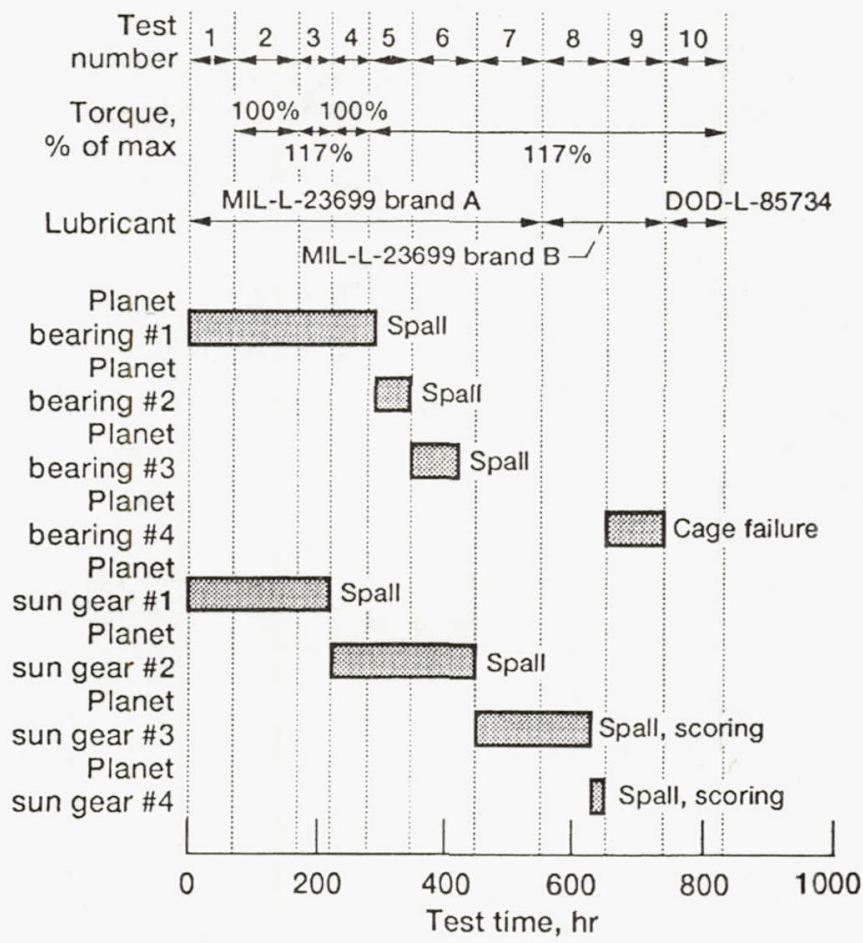

FIG. 3.-Sun gear and planet bearing failures.

Planet bearing failures. For MIL-L-23699 lubricant brand A, three planet bearing fatigue failures occurred. The first occurred on one of the original planet gears of the transmission during test 5 (Fig. 4). The failure was a fatigue spall on the inner race. This component acquired $66 \mathrm{hr}$ of run time at operating conditions of

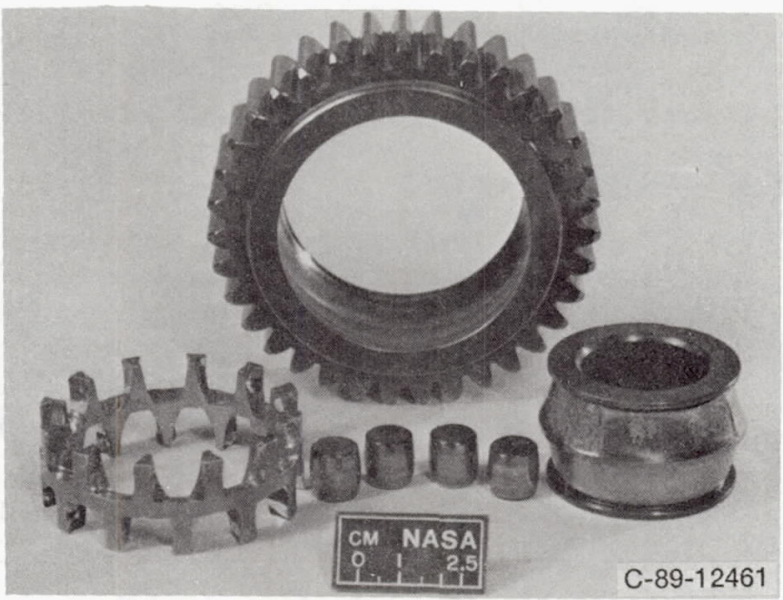

FIG. 4.-Planet bearing fatigue failure during test 5 
117-percent torque and $121^{\circ} \mathrm{C}\left(250^{\circ} \mathrm{F}\right)$ oil inlet temperature from tests 3 and 5 . The second and third planet bearing fatigue failures occurred at these operating conditions. One occurred after $59 \mathrm{hr}$ of test 5 , and the other after $75 \mathrm{hr}$ of test 6 . The failures of all three bearings were similar. The spalls covered both rows of each bearing and about one-third of their circumferences. The large amount of spalling indicates some run time occurred after initial spalling. All failures were detected from the conventional chip detector on the $\mathrm{OH}-58 \mathrm{~A}$ transmission.

For MIL-L-23699 lubricant brand B, one planet bearing cage failure was produced after $91 \mathrm{hr}$ of test 9 (Fig. 5). This failure was catastrophic in that the cage for one of the planet bearings was completely destroyed and the rollers and raceways showed excessive scoring and distress. This failure was detected by a sudden increase in component temperatures and vibration.

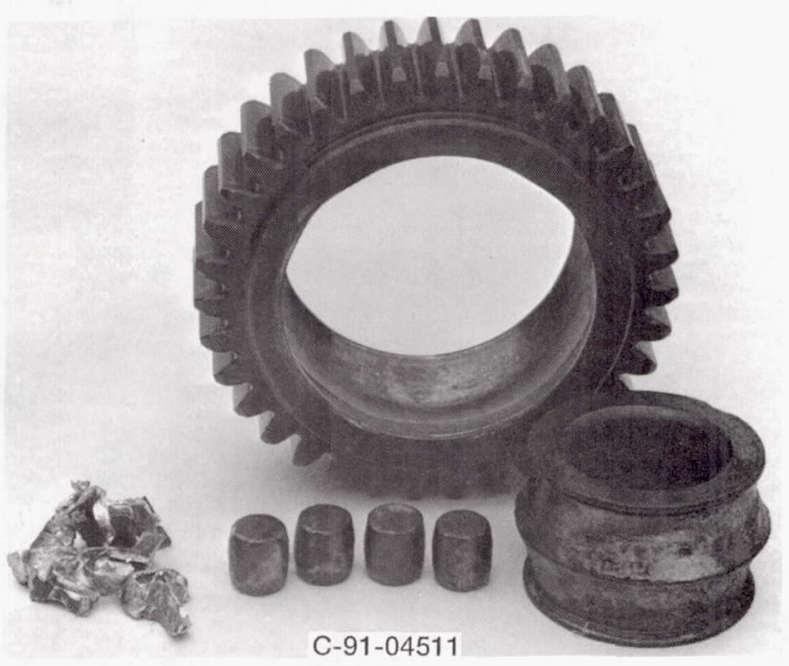

FIG. 5.-Planet bearing cage failure during test 9 .

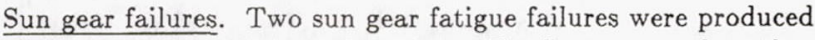
using MIL-L-23699 lubricant brand A. The first occurred on the original sun gear of the transmission after test 3 (Fig. 6). A large fatigue spall occurred on one of its teeth covering nearly threequarters of the face width and much of the tooth load zone. The second sun gear failure occurred after test 6 . This failure was a small pit at the edge of one tooth.

Two sun gear fatigue failures occurred using the MIL-L-23699 lubricant brand B. The first was during test 8 . This gear had spalls and some scoring on many of its teeth. The second sun gear failure occurred after running the last $20 \mathrm{hr}$ of test 8 . This gear again had spalls and some scoring on many of its teeth.

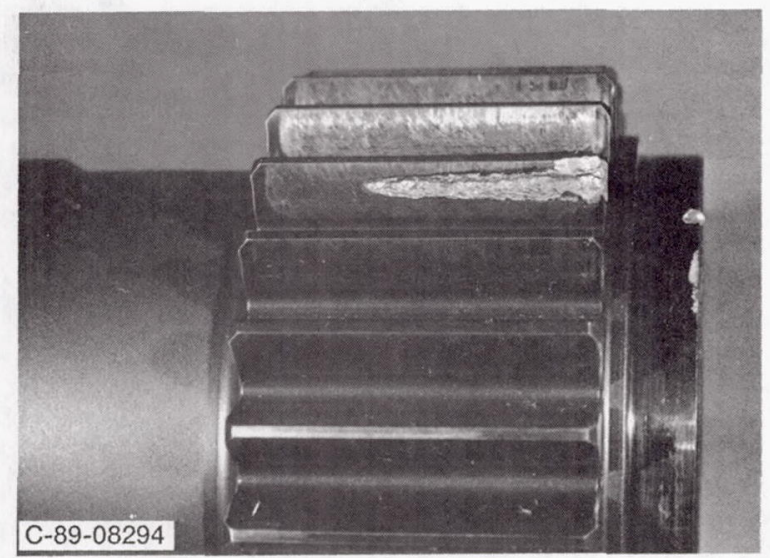

FIG. 6.-Sun gear fatigue failure after test 3.
Additional comments. The testing procedure using operating conditions of 117 -percent torque and $121^{\circ} \mathrm{C}$ oil inlet temperature seemed to produce planetary fatigue failures repeatably using the MIL-L-23699 lubricants. Traditionally, gear and bearing fatigue lives for components run under identical conditions occur with some scatter. Because of the relatively low number of failure data points (compared to conventional component fatigue testing), the confidence level of reproducing failures was not high. Note that the intent of the testing was not, however, to replace gear and bearing component fatigue testing. The intent was to run a transmission with its complex interactions between gears, bearings, and housing, and produce certain types of failures. Thus, from this viewpoint, success was achieved in developing a procedure to produce planetary fatigue failures.

The tests using the MIL-L-23699 lubricant brand A produced planet bearing inner race fatigue failures within about $75 \mathrm{hr}$ when run at 117 -percent torque and $121^{\circ} \mathrm{C}$ oil inlet temperature. This procedure did not produce bearing fatigue failures when run on two successive 100 -hr cases using the MIL-L-23699 lubricant brand B. It is not certain if the difference in results was due to oil differences. With regards to the sun gear, failures occurred at 117-percent torque and $121^{\circ} \mathrm{C}$ oil inlet temperature. However, the results were ambiguous since components were run at different operating conditions. This was primarily done because the tests were performed sequentially, and the results from one test led to the conditions of the next.

As a final note, a single 100-hr run using a DOD-L-85734 lubricant (test 10) did not produce any component failures. This was encouraging in that no failures were produced using this advanced transmission lubricant. Because of the limited amount of data, however, these results by no means demonstrated that the fatigue life of the planetary system using a DOD-L-85734 lubricant was greater than that using a MIL-L-23699. Note that only one test using the DOD-L-85734 oil was performed (because of rig scheduling conflicts).

\section{Mast Shaft Ball Bearing Results}

Only slight success was achieved in developing a testing procedure to produce mast shaft ball-bearing micropitting failures. A total of six bearings were tested and only one resulted in micropitting. The first bearing was used in tests 1 to 4 . After these tests, the bearing was in very good condition with no significant wear marks on the balls or raceways. Note that the bearing was run with a reduced oil flow rate of 1-percent of nominal, which had no effect on the results.

A second bearing was modified as follows. The balls of the bearing were roughened to increase their surface roughness and decrease the elastohydrodynamic film thickness to surface roughness ratio. The bearing was disassembled, and the balls were placed in a glass container, one at a time, with a mixture of $200 \mathrm{~g}$ of 20 -grit silicon carbide and $6.35-\mathrm{mm}(0.25$-in.) steel balls. The container was tumbled at $300 \mathrm{rpm}$ for $6 \mathrm{hr}$. This was repeated for each ball of the bearing. The surface roughness of each ball was measured using a Talysurf measuring system. Some scatter existed in the measured roughnesses between the various balls and also in the measuremerits for each ball. The average ball surface roughness was $0.53 \pm 0.10 \mu \mathrm{m}$ AA $(21 \pm 4 \mu \mathrm{in}$. AA $)$, where $0.10 \mu \mathrm{m}(4 \mu \mathrm{in}$.) was one standard deviation. The bearing was then assembled in the transmission and run $75 \mathrm{hr}$ at 110 -percent of design maximum radial load and at an oil inlet temperature of $121^{\circ} \mathrm{C}\left(250^{\circ} \mathrm{F}\right)$ (test 5). After running and upon inspection, the bearing exhibited micropitting on the inner race (Fig. 7). The bearing ball surface roughnesses were remeasured after running. The average ball surface roughness was reduced to $0.09 \pm 0.02 \mu \mathrm{m} \mathrm{AA}(3.6 \pm 0.7 \mu \mathrm{in}$. AA). Thus, the induced bearing roughness was reduced substantially after running the $75 \mathrm{hr}$.

This testing procedure was repeated with a third bearing. The average ball surface roughness after tumbling was $0.56 \pm 0.13 \mu \mathrm{m} \mathrm{AA}$ $(22 \pm 5 \mu$ in. AA). The bearing was run a total of $100 \mathrm{hr}$ (test 6) at the same operating conditions of the previous bearing that micropitted. After running and upon inspection, the bearing had a 


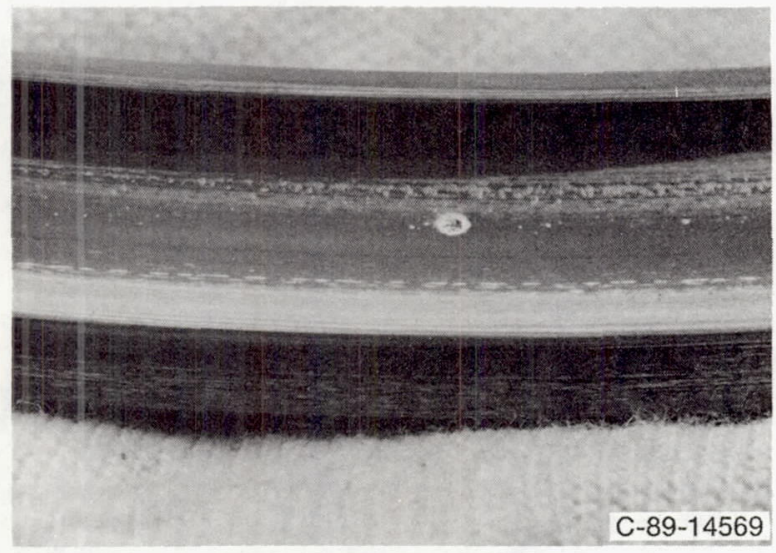

FIG. 7.-Mast shaft ball bearing inner-race micropitting after test 5 .

noticeable wear mark along the load track of the inner race, but micropitting was not evident. The ball surface roughnesses were remeasured, and the average value was $0.09 \pm 0.02 \mu \mathrm{m} \mathrm{AA}$ $(3.7 \pm 0.6 \mu \mathrm{in} . \mathrm{AA})$. Thus, the average ball surface roughness results were nearly identical for tests 5 and 6 for both before and after running the bearing. However, micropitting was not produced from test 6.

A fourth bearing was tumbled and run as was performed above. The average ball surface roughness after tumbling was $0.81 \pm 0.13$ $\mu \mathrm{m} \mathrm{AA}(32 \pm 5 \mu \mathrm{in}$. AA). This surface roughness was higher than that for the previous bearings, even though the tumbling procedure was the same. The bearing was run at 132-percent design maximum radial load (test 7 ). After running, the bearing was inspected. As with the results of test 6 , the bearing had a noticeable wear mark along the load track of the inner race, but micropitting was not evident. The same bearing was used for test 8 . The bearing still exhibited no signs of micropitting after testing.

The fifth bearing tested was run at $91 \mathrm{hr}$ with MIL-L-23699 lubricant brand B (test 9). The bearing balls were not tumbled prior to running. After running, the bearing was in very good condition and looked similar to that of the first bearing tested. The last bearing tested was run $100 \mathrm{hr}$ with the DOD-L-85734 lubricant (test 10). The bearing balls were tumbled prior to running, and the average ball surface roughness after tumbling was $0.61 \pm 0.15 \mu \mathrm{m}$ AA $(24 \pm 6 \mu$ in. AA). After running, the bearing looked similar to those of tests 5 to 7 . In summary, the two bearings that had no surface modifications were in good condition after running, with no significant wear on the balls or raceways. Of the four bearings that had surface modifications, one exhibited micropitting. The remaining three had noticeable wear marks on the inner races but without micropitting.

\section{Spiral-Bevel Mesh Results}

Only slight success was achieved in developing a testing procedure to produce spiral bevel gear scoring failures. The first set of bevel gears tested was unsuccessful in that a fatigue spall was produced on one pinion tooth during the middle of test 2. Other than the spall, both the pinion and the gear showed good contact pattern and no signs of any surface distress. These were the original bevel gears of the transmission.

The second set of bevel gears tested showed signs of heavy wear and light scoring after test 3 (Fig. 8). The set was inspected after test 2 and showed good contact pattern and no surface distress. After test 3 the mesh exhibited heavy wear/light scoring and some micropitting. Heavy wear was evident on the pinion from the root to the tip along most its face width (Fig. 8(a)). The pinion also had small pit lines in the middle of the tooth face and toward the root at the start of contact about 6 to $9 \mathrm{~mm}$ wide. The output gear exhibited heavy wear in the middle of the tooth along most its face width (Fig. $8(\mathrm{~b})$ ). One concern was the high contact pattern that devel-

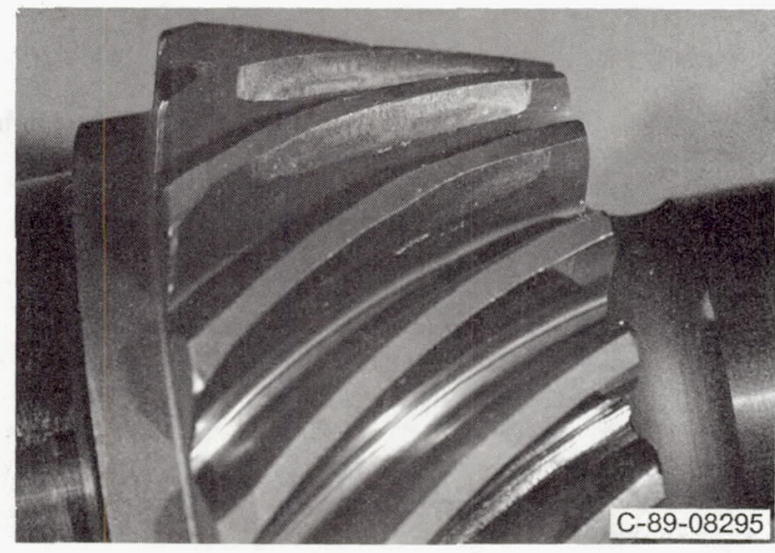

(a) Pinion.

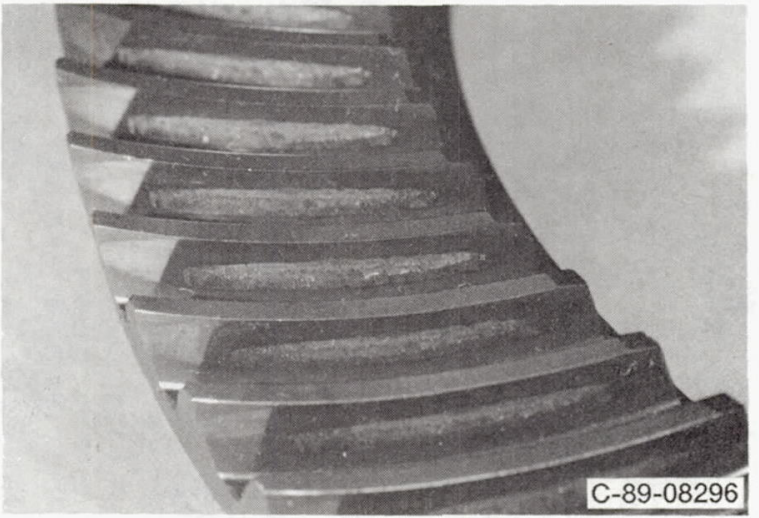

(b) Output gear.

FIG. 8.-Spiral bevel gear mesh heavy wear after test 3.

oped on the pinion (pattern toward the tooth tip). The cause of the high pattern is not known.

A third set of bevel gears was tested to attempt to repeat this failure mode. The third set of gears was initially run $50 \mathrm{hr}$ at 100-percent torque and $121{ }^{\circ} \mathrm{C}$ oil inlet temperature (test 4) to evaluate if high temperature alone would produce scoring. After running, the gear set was inspected; the contact pattern was good, and no tooth distress was produced. The mesh was then run $75 \mathrm{hr}$ at 117 -percent torque and $121^{\circ} \mathrm{C}$ oil inlet temperature (test 5). No tooth distress was produced. The mesh was run an additional $75 \mathrm{hr}$ at these conditions (test 6). Again, no tooth distress was produced.

The lubricant flow rate to the bevel mesh was modified in an attempt to promote tooth scoring. The oil jet to the spiral-bevel mesh was modified by plugging one of the two oil jet holes which lubricated the mesh. The modified oil flow rate was 40 -percent that of the nominal as measured using an external oil pumping system. After running $25 \mathrm{hr}$ at 40 -percent oil flow rate (the last $25 \mathrm{hr}$ of test 6), no signs of tooth distress were evident. The oil jet was further modified by soldering the holes closed and redrilling one of the two jet holes to approximately one-half the original size. This produced an oil flow rate of 21-percent of nominal. The mesh was then run $100 \mathrm{hr}$ at 21-percent oil flow rate and reduced oil level to ensure that the pinion was not submerged in oil (test 7 ). After running and upon inspection, both the pinion and gear exhibited a thin, elliptical wear mark, but no scoring occurred. The wear marks were on the pinion near the root at the start of contact and on the gear near the tip, both extending the majority of the tooth widths. The gears were run an additional $100 \mathrm{hr}$ at these conditions using MIL-L-23699 lubricant brand B (test 8). No change in appearance occurred on the gears after this test.

A fourth and fifth set of bevel gears were tested at these conditions with MIL-L-23699 lubricant brand B and DOD-L-85734 
lubricant (tests 9 and 10, respectively). The gears were in good condition after these tests with no evidence of tooth scoring or distress. Thus, a testing procedure to produce spiral-bevel-gear scoring repeatedly was not achieved.

\section{SUMMARY OF RESULTS}

Experimental tests were performed on the $\mathrm{OH}-58 \mathrm{~A}$ helicopter main-rotor transmission in the NASA 500-hp helicopter transmission test stand. The objective was to develop a procedure to produce sun gear and planet bearing fatigue failures, mast shaft ball-bearing micropitting, and spiral bevel gear scoring. These were components that failed due to marginal lubrication from Navy field experience. The following results were obtained:

1. Success was achieved in developing a testing procedure to produce sun gear and planet bearing fatigue failures. Three planet bearing fatigue failures occurred using a MIL-L-23699 lubricant. Each failure occurred within $75 \mathrm{hr}$ at 117 -percent of design maximum torque and $121^{\circ} \mathrm{C}\left(250^{\circ} \mathrm{F}\right)$ oil inlet temperature. Four sun gear fatigue failures occurred using two different brands of MIL-L-23699 lubricant.

2. Only slight success was achieved in developing a testing procedure to produce mast shaft ball-bearing micropitting. Four bearings had surface modifications performed to roughen their surface finishes and promote marginal lubrication. Of these four, one bearing exhibited micropitting when run in endurance tests.

3. A testing procedure to repeatedly produce spiral bevel gear scoring was not achieved. One set out of five exhibited heavy wear and light scoring when run at 117 -percent torque and $121^{\circ} \mathrm{C}$ oil inlet temperature. Reduced oil flow rate of 21-percent of nominal had very slight effect on tooth surface distress.

\section{REFERENCES}

Brahney, J.H., 1986, "Engine Oils No Longer Suitable For Gearboxes?," Aerospace Engineering, Vol. 6, pp. 67-69.

Drago, R.J., 1982, "Optimum Lubricating Oil Study," Contract No. N00140-82-C-3722, Final Report D210-1965-1, Boeing Vertol Co., Philadelphia, PA.

Drago, R.J., Mangione, P.J., and Wendrzycki, R.D., 1985, “A

Study of the Potential Benefits Associated with the Development of a Dedicated Helicopter Transmission Lubricant," Aviation Gas Turbine Lubricants: Military and Civil Aspects: Aviation Fuel and Lubricants, - Performance Testing, SAE, Warrendale, PA, pp. 59-68 (also SAE paper 851832).
Drago, R.J., 1988, Fundamentals of Gear Design, Butterworth Publishers, Stoneham, MA, pp. 361-377.

Hadden, G.B., Kleckner, R.J., Ragen, M.A., and Sheynin, L., 1981, "Research Report: User's Manual for Computer Program AT81Y003, SHABERTH; Steady State and Transient Thermal Analysis of a Shaft Bearing System Including Ball, Cylindrical and Tapered Roller Bearings," SKF-AT81D040, SKF Industries, Inc., King of Prussia, PA, NASA Contract NAS3-22690, NASA CR-165365.

Keller, Jr., C.H., 1982, "Advanced Technology Helicopter Transmission Lubricant," Contract No. N00140-82-C-3723, Final Report SER510113, Sikorsky Aircraft Division, United Technologies Corp., Bridgeport, CT,

Klecker, R.J., Dyba, G.J., and Ragen, M.A., 1982, Spherical Roller Bearing Analysis; SKF Computer Program SPHERBEAN, Vol. 2, User's Manual, SKF-AT81D007, SKF Industries, Inc., King of Prussia, PA, NASA Contract NAS3-20824, NASA CR-167859.

Lewicki, D.G., and Coy, J.J., 1987, "Vibration Characteristics of OH-58A Helicopter Main Rotor Transmission," NASA TP-2705.

Lewicki, D.G., Decker, H.J., and Shimski, J.T., 1991, "Development of a Full-Scale Transmission Testing Procedure to Evaluate Advanced Lubricants," NASA TP in progress.

Shimski, J.T., and Paskow, L.A., 1985, "Future Trends for U.S.

Naval Aviation Propulsion System Lubricants," Aviation Gas Turbine Lubricants - Military and Civil Aspects: Aviation Fuel and Lubricants - Performance Testing, SAE, Warrendale, PA, pp. 95-102 (also SAE paper 851835).

Townsend, D.P., and Shimski, J.T., 1991, "Evaluation of Advanced Lubricants for Aircraft Applications Using Gear Surface Fatigue Tests," NASA TM-104336.

Wang, K.L., and Cheng, H.S., 1981, "A Numerical Solution to the Dynamic Load, Film Thickness, and Surface Temperature in Spur Gears. Part I, Analysis," Journal of Mechanical Design, Vol. 103, No. 1, pp. 177-187.

Wang, K.L., and Cheng, H.S., 1981, "A Numerical Solution to the Dynamic Load, Film Thickness, and Surface Temperature in Spur Gears. Part II, Results," Journal of Mechanical Design, Vol. 103, No. 1, pp. 188-194.

Warren, N., and Young, J., 1969, "Transmission System Stress Analysis of the Model 206A-1/OH-58A Helicopter," Bell Helicopter Co., Report No. 206-099-119. 
Public reporting burden for this collection of information is estimated to average 1 hour per response, including the time for reviewing instructions, searching existing data sources, gathering and maintaining the data needed, and completing and reviewing the collection of information. Send comments regarding this burden estimate or any other aspect of this collection of information, including suggestions for reducing this burden, to Washington Headquarters Services, Directorate for information Operations and Reports, 1215 Jefferson Davis Highway, Suite 1204, Arlington, VA 22202-4302, and to the Office of Management and Budget, Paperwork Reduction Project (0704-0188), Washington, DC 20503.

\begin{tabular}{|l|l|l} 
1. AGENCY USE ONLY (Leave blank) & $\begin{array}{c}\text { 2. REPORT DATE } \\
\text { September } 1992\end{array}$ & $\begin{array}{r}\text { 3. REPORT TYPE AND DATES COVERED } \\
\text { Technical Memorandum }\end{array}$ \\
\hline
\end{tabular}

4. TITLE AND SUBTITLE

Full-Scale Transmission Testing to Evaluate Advanced Lubricants

6. AUTHOR(S)

David G. Lewicki, Harry J. Decker, and John T. Shimski
5. FUNDING NUMBERS

WU-505-63-36

1L162211A47A
7. PERFORMING ORGANIZATION NAME(S) AND ADDRESS(ES)

NASA Lewis Research Center

Cleveland, Ohio 44135-3191

and

Propulsion Directorate

U.S. Army Aviation Systems Command

Cleveland, Ohio 44135-3191

9. SPONSORING/MONITORING AGENCY NAMES(S) AND ADDRESS(ES)

National Aeronautics and Space Administration

Washington, D.C. $20546-0001$

and

U.S. Army Aviation Systems Command

St. Louis, Mo. $63120-1798$
8. PERFORMING ORGANIZATION REPORT NUMBER

E-7032

11. SUPPLEMENTARY NOTES

Prepared for the Sixth International Power Tansmission and Gearing Conference sponsored by the American Society of Mechanical Engineers, Phoenix, Arizona, September 13-16, 1992. David G. Lewicki and Harry J. Decker, Propulsion Directorate, U.S. Army Aviation Systems Command, and John T. Shimski, Naval Air Propulsion Center, Trenton, New Jersey 08628. Responsible person, David J. Lewicki, (216) 433-3970.

12a. DISTRIBUTION/AVAILABILITY STATEMENT

12b. DISTRIBUTION CODE

Unclassified - Unlimited

Subject Category 37

\section{ABSTRACT (Maximum 200 words)}

Experimental tests were performed on the OH-58A helicopter main-rotor transmission in the NASA Lewis 500-hp helicopter transmission test stand. The testing was part of a joint Navy/NASA/Army lubrication program. The objectives of the joint program are to develop and demonstrate a separate lubricant for gearboxes with improved performance in life and load-carrying capacity. The goal of these experiments was to develop a testing procedure to fail certain transmission components using a MIL-L-23699 based reference oil and then to run identical tests with improved lubricants and demonstrate improved performance. The tests were directed at components that failed due to marginal lubrication from Navy field experience. These failures included mast shaft bearing micropitting, sun gear and planet bearing fatigue, and spiral bevel gear scoring. A variety of tests were performed and over 900 hr of total run time accumulated for these tests. Some success was achieved in developing a testing procedure to produce sun gear and planet bearing fatigue failures. Only marginal success was achieved in producing mast shaft bearing micropitting and spiral bevel gear scoring.

\section{SUBJECT TERMS}

Transmission (machine elements); Lubricants; Gears; Bearings; Scoring; Pitting

17. SECURITY CLASSIFICATION
OF REPORT
Unclassified

18. SECURITY CLASSIFICATION
OF THIS PAGE
Unclassified

19. SECURITY CLASSIFICATION OF ABSTRACT

Unclassified

15. NUMBER OF PAGES

8

16. PRICE CODE

$\mathrm{A} 02$

20. LIMITATION OF ABSTRACT 
National Aeronautics and Space Administration

Lewis Research Center

Cleveland, Ohio 44135

Official Business

Penalty for Private Use $\$ 300$

\section{FOURTH CLASS MAIL}

ADDRESS CORRECTION REQUESTED
Postage and Fees Paid National Aeronautics and Space Administration NASA 451 